\title{
Knowledge of Brazilian dentists and students in treating dentine hypersensitivity
}

\author{
Conhecimento de cirurgiões-dentistas e estudantes brasileirros no tratamento da hipersensibilidade dentinária \\ Conocimiento de estudiantes y dentistas brasileños en el tratamiento de la hipersensibilidad dentinaria
}

Received: 06/15/2021 | Reviewed: 07/14/2021 | Accept: 07/18/2021 | Published: 07/25/2021

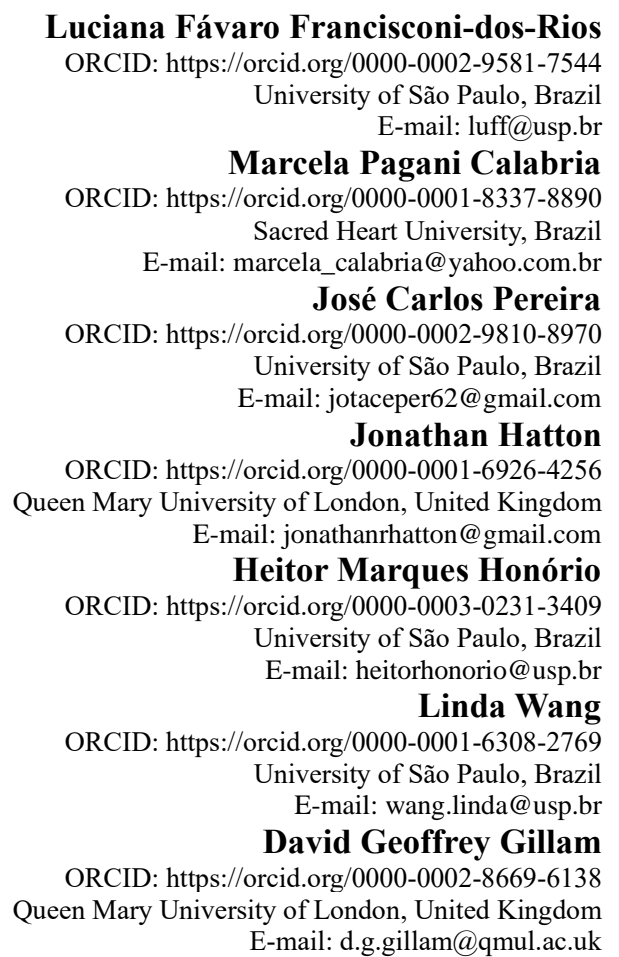

\begin{abstract}
Objective: To evaluate knowledge of undergraduates and qualified dentists from a Brazilian Dental School in treating Dentine Hypersensitivity (DH). Methodology: Data obtained from a 22 -item questionnaire were analyzed and arranged in distribution figures. Results: Of 100 respondents, $66.3 \%$ indicated that up to $25 \%$ of their patients had DH; $41.7 \%$, that the duration of discomfort was up to eight weeks; $78.4 \%$, that they examined a patient with DH within the last twofour weeks; and $70.4 \%$, that this was done after the patient initiated the conversation on DH. Most of participants responded DH affects patients' quality of life, and its aetiology was attrition, exposed dentine, occlusal interference, gingival recession or abrasion. The most common ways to diagnose DH were sensitivity history analysis, clinical examination, clinical testing and probing; and conflicting conditions were fractured restoration, bleaching sensitivity, marginal leakage, chipped tooth and periodontal disease. Furthermore, $82.5 \%$ and $78.7 \%$ of respondents indicated they were confident in diagnosing DH and providing advice to patients, but only $38.8 \%$ identified hydrodynamic theory as its underlying mechanism. To evaluate pain from DH they considered self-assessment, dental examination, dietary analysis and thermal assessment; and as recommendations, the use of desensitizing dentifrices, education on toothbrushing, in-office application of desensitizing products, and restorations. Conclusion: There is still confusion concerning the aetiology, the diagnosis and the subsequent management of $\mathrm{DH}$, and both students and qualified dentists need better education.
\end{abstract}

Keywords: Dentine Hypersensitivity; Knowledge; Teaching; Surveys and Questionnaires.

\section{Resumo}

Objetivo: Avaliar o conhecimento de estudantes e cirurgiões-dentistas de uma Faculdade de Odontologia do Brasil no tratamento da Hipersensibilidade Dentinária (HD). Metodologia: Dados obtidos de um questionário de 22 itens foram analisados e dispostos em gráficos de distribuição. Resultados: De 100 respondentes, 66,3\% indicaram que até $25 \%$ de seus pacientes apresentavam $\mathrm{HD} ; 41,7 \%$, que a duração do desconforto era de até oito semanas; 78,4\%, que examinaram um paciente com HD nas últimas duas-quatro semanas; e 70,4\%, que o fizeram depois que o paciente iniciou a conversa sobre HD. A maioria respondeu que a HD impacta a qualidade de vida dos pacientes e que sua etiologia era atrição, dentina exposta, interferência oclusal, recessão gengival ou abrasão. As formas mais comuns de diagnosticar a HD 
foram análise do histórico de sensibilidade, exame clínico, testes clínicos e tátil; e as condições de confusão, restauração fraturada, sensibilidade ao clareamento, infiltração marginal, dente gretado e doença periodontal. Ainda, 82,5\% e 78,7\% dos respondentes indicaram que se sentiam confiantes ao diagnosticar a HD e aconselhar os pacientes, mas apenas $38,8 \%$ identificaram a teoria hidrodinâmica como seu mecanismo. Para avaliar a dor relativa à HD, consideraram autoavaliação, exame odontológico, avaliação da dieta e testes térmicos; e como recomendações, o uso de dentifrícios dessensibilizantes, educação sobre escovação dentária, aplicação profissional de dessensibilizantes e restaurações. Conclusão: Ainda há confusão quanto à etiologia, ao diagnóstico e ao subsequente manejo da HD, e tanto estudantes quanto cirurgiões-dentistas precisam de melhor orientação.

Palavras-chave: Hipersensibilidade da Dentina; Conhecimento; Ensino; Inquéritos e Questionários.

\section{Resumen}

Objetivo: Evaluar el conocimiento de estudiantes y dentistas de una Facultad de Odontología brasileña en el tratamiento de la Hipersensibilidad Dentinaria (HD). Metodología: Datos obtenidos de un cuestionario de 22 ítems fueron analizados y ordenados en gráficos de distribución. Resultados: De 100 encuestados, 66,3\% indicó que hasta $25 \%$ de sus pacientes tenían HD; 41,7\%, que la duración de las molestias fue de hasta ocho semanas; 78,4\%, que examinó a un paciente con HD en las últimas dos-cuatro semanas; y 70,4\%, que lo realizó después que el paciente iniciara la conversación sobre HD. La mayoría respondió que la HD afecta la calidad de vida de los pacientes y que su etiología era atrición, dentina expuesta, interferencia oclusal, recesión gingival o abrasión. Las formas más comunes de diagnosticar la HD fueron análisis de la historia de sensibilidad, exploración clínica, pruebas clínicas y táctiles; y las condiciones de confusión, restauración fracturada, sensibilidad al blanqueamiento, infiltración marginal, diente fracturado y enfermedad periodontal. Además, $82,5 \%$ y 78,7\% de los encuestados indicaron que se sentían seguros al diagnosticar la HD y asesorar a los pacientes, pero solo 38,8\% identificó la teoría hidrodinámica como su mecanismo. Para evaluar el dolor por HD, consideraron autoevaluación, examen dental, evaluación de dieta y pruebas térmicas; y como recomendaciones, el uso de pastas dentales desensibilizantes, educación sobre cepillado dental, aplicación profesional de desensibilizantes y restauraciones. Conclusión: Aún existe confusión en cuanto la etiología, el diagnóstico y el manejo posterior de la HD, y tanto estudiantes como odontólogos necesitan mejor orientación.

Palabras clave: Hipersensibilidad de la Dentina; Conocimiento; Enseñanza; Encuestas y Cuestionarios.

\section{Introduction}

Dentine hypersensitivity (DH), derived from this tissue exposure to the oral environment, has been recognized as an important clinical issue for years (Splieth \& Tachou, 2013). It is a dental condition that initiates a sharp pain which is transient in nature following drinking cold water, acidic food and drinks, dental procedures such as cold air from a dental triple air syringe, non-surgical and surgical periodontal procedures (Orchardson \& Gillam, 2006). Due to DH, a significant proportion (about 25\%) of patients experience discomfort during their day-to-day activities such as eating, drinking etc. (Gillam, et al., 1999; McGrath, et al., 2005), and a considerable adverse impact on their quality of life (QoL) (Bekes, et al., 2009). There are indications that DH may affect 3 to $98 \%$ of the population, although evidences still point out it should be deeper epidemiologically studied (Splieth \& Tachou, 2013).

The clinical diagnosis of $\mathrm{DH}$ is a critical component in the management of the condition but there are several compounding issues that may impact on it. For example, a proportion of those suffering from DH fail to consult a clinician and may either self-treat using desensitizing toothpaste or simply live with the problem depending on how it affects their QoL (Graham, et al., 2003). A second issue highlighted by a Consensus Document (Canadian Advisory Board on Dentin Hypersensitivity, 2003) was that DH was not routinely conducted by clinicians except when prompted by patients with DH. Differential diagnosis from other kinds of dental sensitivity, such as that related with molar incisor hypomineralization (MIH) (Laureano, et al., 2020; Raposo, et al., 2019) or bleaching (Peixoto, et al., 2019) is also often overlooked. Finally, DH treatment should be driven considering not only the event itself but also the dentist's and mainly the patient's perceptions and expectations (Canadian Advisory Board on Dentin Hypersensitivity, 2003).

Quality of life (QoL) of individuals plus understanding of the issue by the professionals thus endorse surveys as relevant tools to search for more precise and long-lasting approaches (Paiva, et al., 2019). As part of a collaborative study with the Barts and the London School of Medicine and Dentistry, QMUL, London, United Kingdom (Hatton, et al., 2012; Hatton, et al., 2020), 
this questionnaire-based study aimed to evaluate the knowledge and understanding of dental undergraduates and qualified dentists from a Brazilian Dental School in treating DH. The questions arisen were whether 1) did they understand the basic principles underlying DH in terms of aetiological causes, mechanisms of action etc., and 2) were they able to successfully diagnose and manage $\mathrm{DH}$.

\section{Methodology}

A questionnaire used before (Hatton, et al., 2012; Hatton, et al., 2020), consisting of both open and closed questions (Q; 22 in total), was translated from English into Brazilian Portuguese and handed out to undergraduate students, postgraduate students and Staff at the Bauru School of Dentistry, University of São Paulo, Brazil, over a three-month period, after the study was approved by its Ethics Committee for Human Studies (CAAE 0065.0.224.00-11; Process \#066/2011). Number of responses to be expected for both the Barts and the London School of Medicine and Dentistry study (Hatton, et al., 2012; Hatton, et al., 2020) and the present one was based on a previous pilot study in The Royal London Dental Hospital, United Kingdom. Data from the answers were entered using Microsoft Excel, and the results analysed using SPSS 22.0 for Windows (IBM, Portsmouth UK) and presented in the form of distribution figures.

\section{Results}

Of the one hundred participants who responded the handed-out questionnaires, 69\% (n=69) were female, 22\% (n=22) were male with 9\% ( $\mathrm{n}=9)$ missing info; mean age was 33.05 (SD 11.09) years. Their professional status involved 73\% ( $\mathrm{n}=73$ ) dentists, $13 \%(n=13)$ dental students, and $9 \%(n=9)$ postgraduate students with $5 \%(n=5)$ missing values. Of respondents who stated their clinical experience, there was a range of it going from those with $<5$ years' experience $(27.7 \%, \mathrm{n}=26)$ up to 50 years of clinical experience $(50.0 \%, \mathrm{n}=47)$ with the remainder either non-graduated or under postgraduate training $(22.3 \%, \mathrm{n}=21)$. They were either in Academia (32.0\%, $n=25)$, Private Office (29.5\%, $n=23)$, Public Service (16.7\%, $n=13$ ), and a mixture of Public/Private Office $(11.5 \%, n=9)$ or Academia/Private Office $(10.3 \% ; n=8)$. Most of them estimated that their practice base was $<499$ patients $(35.2 \%$; $n=32)$ with $38.5 \%(n=35)$ unsure of the number of patients in their practice (Q1).

When asked if they had examined a patient with DH in the last two-four weeks/month (Q2), 78.4\% ( $\mathrm{n}=76)$ of the respondents indicated that they had examined a patient whereas $21.6 \%(n=21)$ said that they did not examine a patient with $\mathrm{DH}$ during this period. Sixty-six point three percent $(66.3 \%, \mathrm{n}=63)$ of the respondents also indicated that the prevalence of DH was up to $25 \%$ (range $1 \%$ to $25 \%$ ) (Q3). In response to $\mathrm{Q} 4,70.4 \%(\mathrm{n}=69)$ of the respondents indicated that the patient initiated the conversation on DH whereas $29.6 \%(n=29)$ indicated that the patient did not initiate the conversation. When asked whether the clinician initiated the conversation regarding DH, 75.7\% ( $\mathrm{n}=56$ ) indicated that they (the clinician) had initiated the conversation rather than the patient (Q5).

In response to $\mathrm{Q} 6,89.8 \%(\mathrm{n}=88)$ of the respondents reported that they had observed the signs associated with $\mathrm{DH}$. When asked whether they considered DH to be a serious clinical problem (Q7), up to 76.6\% ( $\mathrm{n}=69)$ of the respondents indicated that $\mathrm{DH}$ was a serious problem (range $1 \%$ to $75 \%$ ) with $7.8 \%(\mathrm{n}=7)$ stating that $\mathrm{DH}$ was not a serious problem with their patients; $15.6 \%(\mathrm{n}=14)$ did not know if $\mathrm{DH}$ was a serious problem. There were ten missing values.

When asked how long was the duration of discomfort from $\mathrm{DH}(\mathrm{Q} 8), 41.7 \%(\mathrm{n}=40)$ of the respondents provided a range of discomfort up to eight weeks with $25 \%(\mathrm{n}=24)$ of respondents indicating that the duration lasted more than 12 weeks. Thirty three point three percent $(33.3 \%, \mathrm{n}=32)$ did not know how long the discomfort from DH lasted (Figure 1). There were four missing values. 
Figure 1: Duration of discomfort - percentage responses.

\section{Duration of Discomfort (\% Response)}

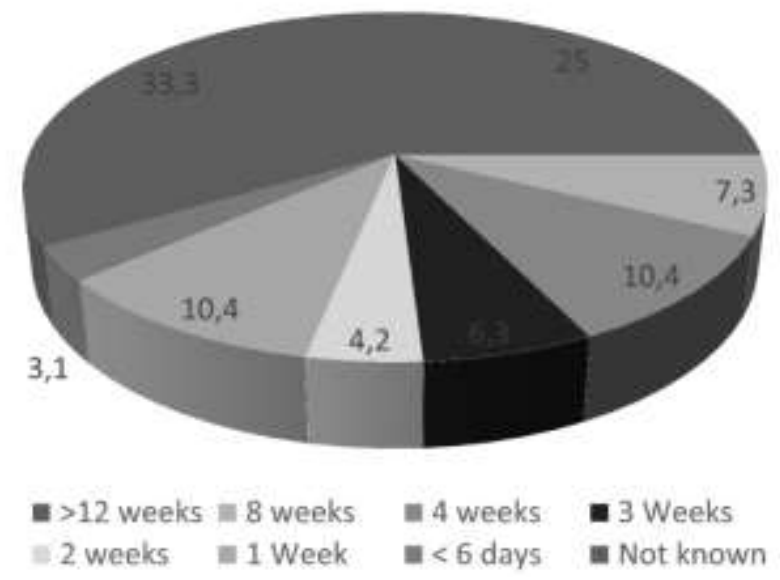

Source: Authors.

When asked whether DH had a major impact on the QoL of their patients, $90.8 \%$ of the respondents indicated that DH had a major impact on the QoL, with $85.7 \%(n=78)$ indicating that this impact was mild to moderate in nature and $14.3 \%(n=13)$ indicating that the impact was severe in nature. There were nine missing values (Q9 and Q10). Ninety-five point nine percent $(95.9 \%, \mathrm{n}=94)$ of the respondents indicated they were routinely asked about DH, with $48 \%(\mathrm{n}=47)$ of these questions were asked either "very often" or "often" and $48 \%(n=47)$ of respondents were asked either "sometimes" or "seldom" by their patients. Four point one percent $(4.1 \%, \mathrm{n}=4)$ indicated that they were never asked about the condition $(\mathrm{Q} 11)$.

Main responses regarding the aetiology of DH (Q12) were 1) attrition (46\%; $n=46), 2)$ exposed dentine (45\%; $n=45)$, 3) occlusal interference $(37 \% ; n=37), 4)$ gingival recession $(35 \% ; n=35)$, and 5) abrasion (32\%; $n=32)$ (Figure 2).

Figure 2: The aetiology of Dentine Hypersensitivity (selected variables).

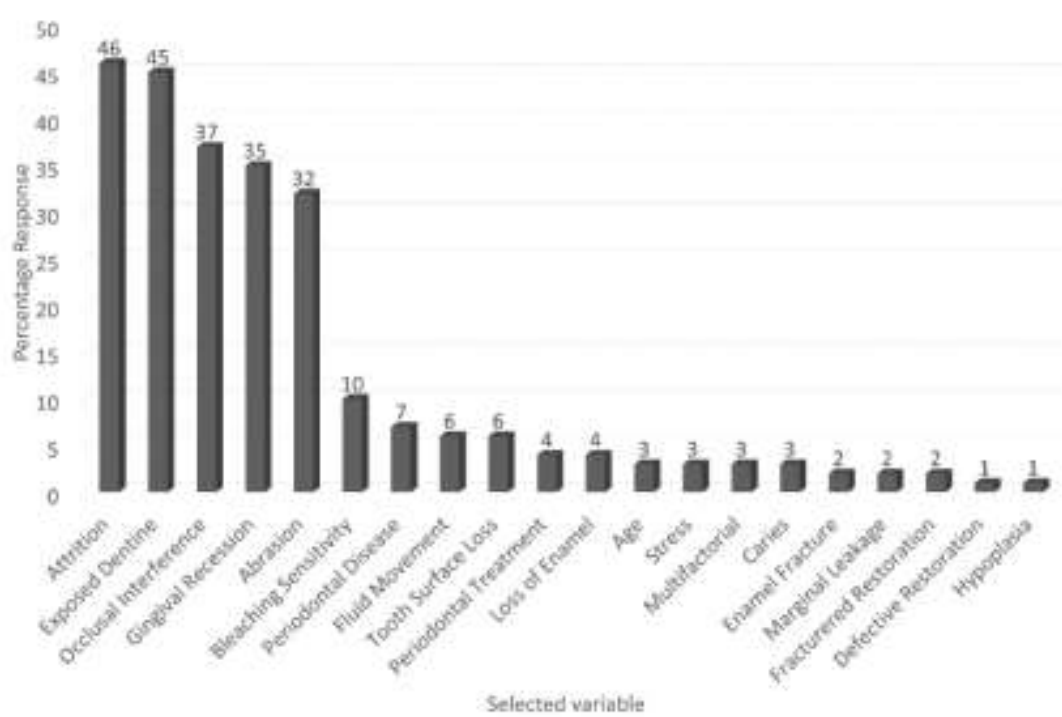

Source: Authors. 
When asked to respond to the question on the steps taken to clinically diagnose a patient with DH (Q13), the five most common diagnostic tools recommended by the respondents were 1) DH history $(62 \%, \mathrm{n}=62), 2)$ clinical examination $(52 \%$, $\mathrm{n}=52), 3)$ clinical sensitivity testing to cold $(34 \%, \mathrm{n}=34), 4)$ clinical testing (evaporative) $(28 \%, \mathrm{n}=28)$, and 5$)$ probing $(15 \%$, $\mathrm{n}=15$ ). There was also a range of other responses (Figure 3).

Figure 3: Steps taken to clinically diagnose a patient with DH.

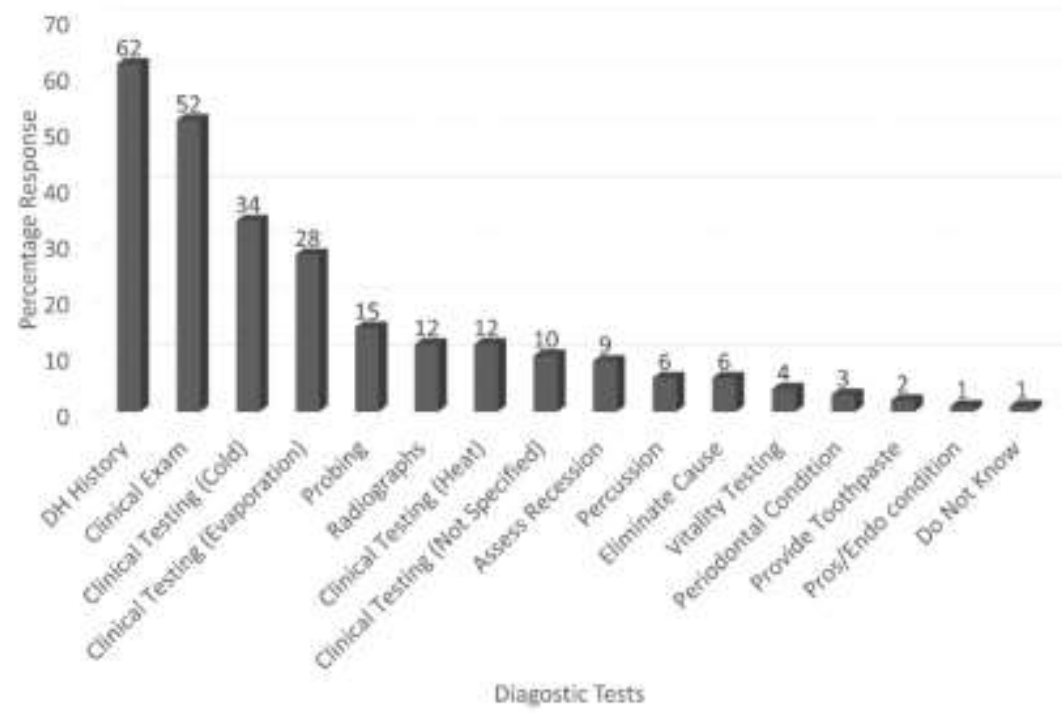

Source: Authors.

When asked, what other dental conditions would you take into consideration when making a diagnosis of DH (Q14), the main responses were as follows: 1) fractured restoration $(79.6 \%, \mathrm{n}=78), 2)$ bleaching sensitivity $(76.5 \%, \mathrm{n}=75), 3)$ marginal leakage $(75.5 \% ; \mathrm{n}=74), 4)$ chipped tooth $(72.4 \%, \mathrm{n}=71), 5)$ periodontal disease $(71.4 \%, \mathrm{n}=70), 6)$ post-operative sensitivity $(67.3 \%, n=66), 7)$ dental caries $(64.3 \% ; n=63), 8)$ cracked tooth syndrome $(55.1 \%, n=54)$ and 9$)$ pulpitis $(53.1 \%, n=52)($ Figure 4).

Figure 4: Other dental conditions taken into consideration when making a diagnosis of DH.

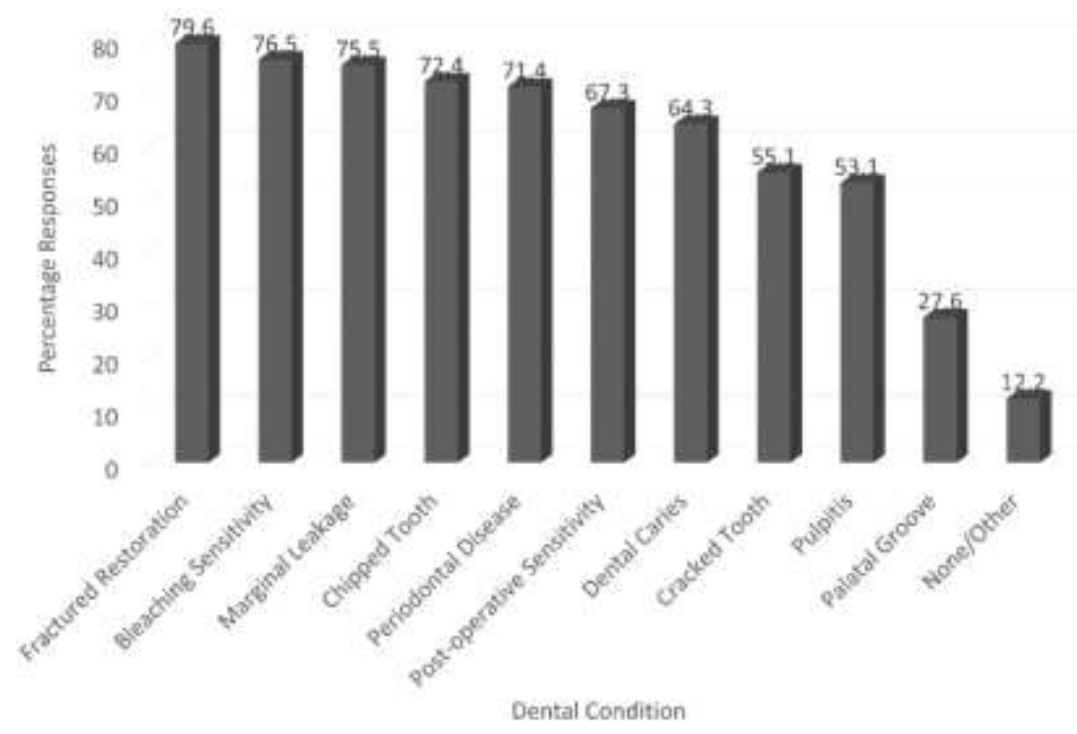

Source: Authors.

The responses to Q15 on how confident the respondents were in correctly diagnosing DH by excluding other dental 
conditions indicated that $82.5 \%(\mathrm{n}=80)$ of the respondents expressed a degree of confidence when determining a definitive diagnosis of DH with $17.6 \%(n=17)$ indicating that they were either "Not very confident" (15.5\%) or "Not at all confident" $(2.1 \%)$. There were three missing values. When asked about the currently accepted theory of DH $(\mathrm{Q} 16), 38.8 \%(\mathrm{n}=38)$ of the respondents indicated that recognised that the hydrodynamic theory was the underlying mechanism of DH with $34.7 \%(\mathrm{n}=34)$ indicating that "other mechanisms" (not specified) were responsible. Eight point two percent $(8.2 \%$, n=8) did not know which theory was responsible for the discomfort associated with DH.

When assessing or evaluating patients who complain of dental pain including DH (Q17), the five main assessment methods based on the number of positive responses were as follows: 1) self evaluation (99\%, $\mathrm{n}=97)$, 2) dental examination $(82.7 \%, \mathrm{n}=81), 3)$ dietary analysis $(63.6 \%, \mathrm{n}=62), 4)$ thermal tests $(55.1 \%, \mathrm{n}=54)$ and 5) periodontal assessment (measurement of recession) $(51 \%, \mathrm{n}=50)$. There was also further diagnostic tests that were mentioned by the respondents such as medical history $(33.7 \%, \mathrm{n}=33)$, dental radiographs $(27.6 \%, \mathrm{n}=27)$, percussion tests $(23.5 \%, \mathrm{n}=23)$, periodontal assessment (pocket depth) $(22.4 \%, \mathrm{n}=22)$, pulpal tests $(21.4 \%, \mathrm{n}=21)$ and other options (not specified) $(8.2 \%, \mathrm{n}=8)$ (Figure 5).

Figure 5: Ways to assess/evaluate patients complaining of DH in the surgery environment.

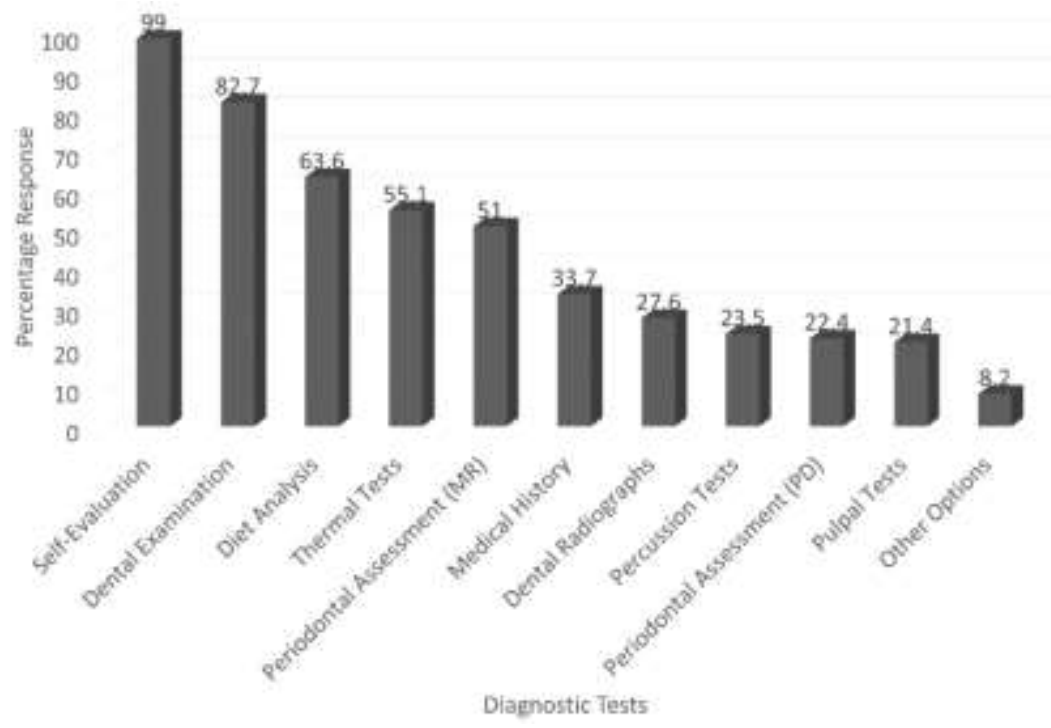

Source: Authors.

The advice and treatment recommended by the respondents to their patients experiencing DH (Q18) was in reasonable agreement as follows: 1) at home desensitizing dentifrice (97\%, n=97), 2) education on toothbrushing (97\%, n=97), 3) in-surgery application of a desensitizing agent $(92 \%, \mathrm{n}=92), 4)$ restorative treatment $(88 \%, \mathrm{n}=88)$ and 5$)$ other options (not specified) (17\%, $\mathrm{n}=17)$. Q19 asked the respondents to indicate how confident they were when recommending the appropriate advice or treatment to their patients experiencing DH. Most respondents $(78.7 \%, \mathrm{n}=78)$ expressed that they were reasonably confident in recommending advice to their patients $(22.2 \%, \mathrm{n}=22$ - very confident; $44.4 \%, \mathrm{n}=44$ - confident; $12.1 \%, \mathrm{n}=12$ - somewhat confident) with $21.3 \%(n=21)$ of the respondents indicating that they were either "not very confident" $(15.2 \%, n=15)$ or "not at all confident" $(6.1 \%, \mathrm{n}=6)$.

In response to Q20, regarding whether patients experiencing non-dental problems (such as stress etc.) in their daily life which may contribute to $\mathrm{DH}, 64 \%(\mathrm{n}=64)$ that such problems may contribute to the condition with $23 \%$ ( $\mathrm{n}=23$ ) respondents indicating that non-dental problems were not contributing to $\mathrm{DH}$. Thirteen percent $(13 \%, \mathrm{n}=13)$ indicated that they did not know if non-dental problems contributed to $\mathrm{DH}$.

When asked to elaborate on whether there were any specific non-dental problems associated with DH (Q20), there were 
89 responses $(89 \%)$ which included 1) stress $(49 \%, \mathrm{n}=49), 2)$ psychological $(\mathrm{n}=34 \%, \mathrm{n}=34), 3)$ medical conditions $(25, \mathrm{n}=2), 4)$ $\operatorname{diet}(2 \%, \mathrm{n}=2)$ and 5$)$ other options (not specified) $(2 \%, \mathrm{n}=2)$.

Through Q21, the respondents were asked if their patients frequently complied with the professional advice they provided for the treatment and management of DH. In response, 33\% $(n=33)$ indicated that their patients did comply with their advice with $51 \%(\mathrm{n}=51)$ disagreeing; $16 \%(\mathrm{n}=16)$ did not know whether their patients complied with their recommendations. When asked whether there was a need for additional information to prevent further occurrences of DH in the form of a leaflet etc. (Q22), 75\% ( $\mathrm{n}=75)$ of the respondents indicated that there was a need for a patient leaflet with $57 \%(\mathrm{n}=57)$ of the respondents indicating that further supplementary information should be provided for their patients. These responses $(\mathrm{n}=71)$ included: 1$)$ hypersensitivity advice $(\mathrm{n}=10), 2)$ dietary advice $(\mathrm{n}=11), 3)$ toothbrushing advice $(\mathrm{n}=9), 4)$ symptom information $(\mathrm{n}=7), 5)$ other options (not specified; $n=7), 6$ ) home use products $(n=6), 7)$ preventive advice $(n=5), 8)$ use of high fluoride concentration (toothpaste) $(n=5), 9)$ modification of toothbrushing techniques $(n=4), 10)$ DH education $(n=3), 11)$ see dentist $(n=2), 12)$ occlusal advice ( $\mathrm{n}=1)$ and 13) does not know $(\mathrm{n}=1)$.

\section{Discussion}

It was originally anticipated that it would be possible to compare the responses of the students and staff but this was not factual due to the mismatch in the numbers and therefore, the data from the returned questionnaires were analysed as one group. The responses analysed in this study were in general agreement with previous questionnaires although there were some discrepancies in relation to the aetiology, diagnosis and management of DH. It is clear that there is no overall consensus in the management of DH particularly with respect to the products recommended for treating it (Canadian Advisory Board on Dentin Hypersensitivity, 2003; Cunha-Cruz, et al., 2010; Exarchou, et al., 2019; Gillam, et al., 2002; Gillam, et al., 2019; Hatton, et al., 2012; Hatton, et al., 2020; Izhar, et al., 2019; Kopycka-Kedzierawski, et al., 2017; Pereira, et al., 2018; Schuurs, et al., 1995; Zeola, et al., 2020).

The assertions from the Canadian Consensus document (Canadian Advisory Board on Dentin Hypersensitivity, 2003) that not only is the condition under reporting of DH by clinicians as well as a lack of confidence in the management of DH appear to be supported from the results observed in the present study. The referred document (Canadian Advisory Board on Dentin Hypersensitivity, 2003) is still a foundational document for the management of DH and its main recommendations were based on both clinical and scientific evidence enabling clinicians to be aware of the aetiology, predisposing factors, diagnosis, management and education. Unfortunately, despite these recommendations, it is clear from the various studies on the awareness, perception and knowledge that clinicians still have problems in managing $\mathrm{DH}$, particularly in the recommendation of desensitizing products where a vast range of products have been suggested by the respondents in these studies (Canadian Advisory Board on Dentin Hypersensitivity, 2003; Cunha-Cruz, et al., 2010; Kopycka-Kedzierawski, et al., 2017).

Besides, clinicians are either under-diagnosing or misdiagnosing DH as well as lacking the confidence to manage the condition (Gillam, et al., 2013) partly due to a lack of understanding with the causes of DH. For example, in the various published studies numerous aetiological factors were suggested such as attrition, abrasion, gingival recession, erosion etc. (Canadian Advisory Board on Dentin Hypersensitivity, 2003; Gillam, et al., 1999; Cunha-Cruz, et al., 2010; Gillam, et al., 2002; Izhar, et al., 2019; Kopycka-Kedzierawski, et al., 2017; Schuurs, et al., 1995; Zeola, et al., 2020), however some of these suggestions are not supported by the evidence (Canadian Advisory Board on Dentin Hypersensitivity, 2003). For example, attrition, abrasion and gingival recession together with over-zealous toothbrushing, periodontal procedures etc., have been suggested as primary aetiological causes for the development of DH, however, it is accepted that "erosion" is the primary cause of DH (Canadian Advisory Board on Dentin Hypersensitivity, 2003). In the present study none of the respondents included "erosion" in their responses. As with most other published studies, "gingival recession" was incorrectly as the most common cause of DH even 
though it is an established predisposing factor (Canadian Advisory Board on Dentin Hypersensitivity, 2003; Gillam, et al., 1999; Pereira, et al., 2018). Other incorrect variables identified in the present study were occlusal interferences (37\%, $\mathrm{n}=37)$ and bleaching sensitivity $(10 \% ; \mathrm{n}=10)$ : neither of which are recognised as triggers of DH (Canadian Advisory Board on Dentin Hypersensitivity, 2003; Gillam, et al., 2013).

In the present study, the most respondents indicated that DH could last up to eight weeks, which contradicts the recognised assumption that DH is a transient pain, and would therefore suggest that from a diagnostic perspective that other causes of dental pain may also complicate the diagnosis of DH by clinicians. It is also evident that the impact of DH on the QoL has often been overlooked although this aspect has been addressed by in some publications (Bekes, et al., 2009; Douglas-deOliveira, et al., 2018; Gillam, et al., 2013). The severity of the impact of DH however is unclear. In the present study, the respondents indicated that DH had a mild to moderate impact on the QoL, which has already been shown before (Gillam, et al., 2002).

As with most published questionnaire studies on DH clinicians provide a wide range of diagnostic steps when determining DH from other clinical conditions, in the present study the main clinical steps included a history of DH, clinical examination, clinical testing (cold and evaporative) and probing (Cunha-Cruz, et al., 2010; Gillam, et al., 2002; Izhar, et al., 2019; Kopycka-Kedzierawski, et al., 2017; Schuurs, et al., 1995; Zeola, et al., 2020). There was also a wide range of clinical assessments used to evaluate pain from DH including self-assessment, dental examination, dietary analysis, and thermal assessment etc. which may indicate a degree of uncertainty when developing a differential diagnosis or there could be conflicting pain symptoms which would include additional diagnostic testing such as radiographs and vitality testing (Cunha-Cruz, et al., 2010; Gillam, et al., 2013). It would however be prudent to exclude pain arising from other sources such periodontal problem, referred pain, neuropathic pain and, chronic pain syndromes (Canadian Advisory Board on Dentin Hypersensitivity, 2003). Most respondents $(82.5 \%, \mathrm{n}=80)$ in the present study indicated that were confident in diagnosing $\mathrm{DH}$ which is not supported by other studies where has been a degree of uncertainty in the level of confidence in diagnosing and managing DH (Canadian Advisory Board on Dentin Hypersensitivity, 2003; Gillam, et al., 2002; Schuurs, et al., 1995; Zeola, et al., 2020).

A continuing concern that had been previously identified is the level of understanding regarding the mechanism of action underpinning DH (Canadian Advisory Board on Dentin Hypersensitivity, 2003) as with other studies the level of understanding of the mechanism of DH (e.g., the hydrodynamic theory) was poor with only $38.8 \%(\mathrm{n}=38$ ) of the respondents correctly identified the hydrodynamic theory as the underlying mechanism of DH (Canadian Advisory Board on Dentin Hypersensitivity, 2003). Care should however be taken in extrapolating the results from this hospital-based study to the general practice situation.

It should also be recognised that the diagnosis of oral facial pain including DH is not straightforward and may challenge clinicians' in general dental practice (Canadian Advisory Board on Dentin Hypersensitivity, 2003; Gillam, et al., 2013; Zeola, et al., 2020) but it is also evident that there still is a degree of confusion on the overall management of DH. To attempt to overcome this deficiency it seems interesting to follow guidelines and educational initiatives to provide clinicians with a degree of clarity in the overall understanding of the aetiology, diagnosis and, subsequent management of the condition (Canadian Advisory Board on Dentin Hypersensitivity, 2003; Kopycka-Kedzierawski, et al., 2017).

\section{Conclusion}

Finally, in terms of knowledge and understanding of DH, there is still confusion among Brazilian dentists and students concerning some aspects of the aetiology, diagnosis and subsequent management of the condition. It seems reasonable that further education at both pre-graduation and graduation levels is required to apprise them on the management of DH. 
Changes to the dental curriculum and cpd (continuing professional development) courses should thus be investigated as means to enhance the ability of dental professionals to successfully treat this clinical problem.

\section{Acknowledgments}

This study was financed to enable the fourth author to visit Brazil by a grant from GSK, but the Company were not involved in the study design or in the collection, analysis and interpretation of data; in the writing of the report; and in the decision to submit the article for publication.

\section{References}

Bekes, K., John, M. T., Schaller, H. G., \& Hirsch, C. (2009). Oral health related quality of life in patients seeking care for dentin sensitivity. Journal of Oral Rehabilitation, 36(1), 45-51. 10.1111/j.1365-2842.2008.01901.x

Canadian Advisory Board on Dentin Hypersensitivity. (2003). Consensus based recommendations for the diagnosis and management of dentin hypersensitivity. Journal of the Canadian Dental Association, 69(4), 221-226. Retrieved from http://www.cda-adc.ca/jcda/vol-69/issue-4/221.pdf

Cunha-Cruz, J., Wataha, J. C., Zhou, L., Manning, W., Trantow, M., Bettendorf, M. M., Heaton, L. J., \& Berg, J. (2010). Treating dentin hypersensitivity: therapeutic choices made by dentists of the northwest PRECEDENT network. The Journal of the American Dental Association, 141(9), 1097-1105. 10.14219/jada.archive.2010.0340

Douglas-de-Oliveira, D. W., Vitor, G. P., Silveira, J. O., Martins, C. C., Costa, F. O., \& Cota, L. O. M. (2018). Effect of dentin hypersensitivity treatment on oral health related quality of life - a systematic review and meta-analysis. Journal of Dentistry, 71, 1-8. 10.1016/j.jdent.2017.12.007

Exarchou, C., Betsani, I., Sakellari, D., Chatzopoulou, D., \& Gillam, D. (2019). A Survey of dentists in the management of dentine hypersensitivity: a questionnaire-based study. European Journal of Dentistry, 13(3), 383-390. 10.1055/s-0039-1694306

Gillam, D. G. (2013). Current diagnosis of dentin hypersensitivity in the dental office: an overview. Clinical Oral Investigations, 17 Suppl 1(Suppl 1), S21-S29. $10.1007 / \mathrm{s} 00784-012-0911-1$

Gillam, D. G., Bulman, J. S., Eijkman, M. A., \& Newman, H. N. (2002). Dentists' perceptions of dentine hypersensitivity and knowledge of its treatment. Journal of Oral Rehabilitation, 29(3), 219-225. 10.1046/j.1365-2842.2002.00812.x

Gillam, D. G., Dashti, N., \& Chatzopoulou, D. (2019). A Survey of the professional opinions of Kuwaiti dentists for the treatment and management of dentine hypersensitivity: a questionnaire-based study. Jacobs Journal of Dentistry and Research, 5(2), 046. https://qmro.qmul.ac.uk/xmlui/handle/123456789/62942

Gillam, D. G., Seo, H. S., Bulman, J. S., \& Newman, H. N. (1999). Perceptions of dentine hypersensitivity in a general practice population. Journal of Oral Rehabilitation, 26(9), 710-714. 10.1046/j.1365-2842.1999.00436.x

Graham, F. L., Tatton-Brown, C., Meert, G., \& Alexander, D. C. (2003). Prevalence and severity of dentin hypersensitivity: a global perspective. Journal of Dental Research, 82(special issue B), 0970. https://iadr.abstractarchives.com/abstract/2003Goteborg-31151/prevalence-and-severity-of-dentin-hypersensitivitya-global-perspective

Hatton, J., Kumar, K., \& Gillam, D. G. (2012). Knowledge of dental undergraduates and dentists in treating dentine hypersensitivity. Journal of Dental Research, 91(Spec Iss B), 2294. https://iadr.abstractarchives.com/abstract/2012rio-166398/knowledge-of-dental-undergraduates-and-dentists-in-treating-dentinehypersensitivity

Hatton, J., Kumar, K., \& Gillam, D. G. (2020). Knowledge of dental undergraduates and dentists in treating dentine hypersensitivity. Dental Oral Biology and Craniofacial Research Journal, 3(3), 2-6. https://www.sciencerepository.org/knowledge-of-uk-dental-undergraduates-and-dentists-in-treatingdentine_DOBCR-2020-3-101

Izhar, F., Nazir, M. A., Majeed, A., \& Almas, K. (2019). Dentists' knowledge and practice of dentine hypersensitivity. European Journal of Dentistry, 13(4), 540-546. 10.1055/s-0039-1697110

Kopycka-Kedzierawski, D. T., Meyerowitz, C., Litaker, M. S., Chonowski, S., Heft, M. W., Gordan, V. V., Yardic, R. L, Madden, T. E., Reyes, S. C., Gilbert, G. H., \& National Dental PBRN Collaborative Group. Management of dentin hypersensitivity by National Dental Practice-Based Research Network practitioners: results from a questionnaire administered prior to initiation of a clinical study on this topic. BMC Oral Health, 17(1), 41. 10.1186/s12903-0170334-0

Laureano, I. C. C., Farias, L., Fernandes, L. H. F., Alencar, C. R. B., Forte, F. D. S., Honório, D. R., \& Cavalcanti, A. L. (2020). Dental fear in children: association with dental caries and molar incisor hypomineralization. Brazilian Dental Journal, 31(6), 673-679. 10.1590/0103-6440202003880

McGrath, C., Wong, A. H. H., Lo, E. C. M., \& Cheung, C. S. (2005). The sensitivity and responsiveness of an oral health related quality of life measure to tooth whitening. Journal of Dentistry, 33(8), 697-702. 10.1016/j.jdent.2005.01.012

Orchardson, R., \& Gillam, D. G. (2006). Managing dentin hypersensitivity. The Journal of the American Dental Association, 137(7), 990-998. 10.14219/jada.archive.2006.0321

Paiva, S. M., Perazzo, M. F., Ortiz, F. R., Pordeus, I. A., \& Martins-Júnior, P. A. (2018). How to select a questionnaire with a good methodological quality? Brazilian Dental Journal, 29(1), 3-6. 10.1590/0103-6440201802008 
Research, Society and Development, v. 10, n. 9, e28010917194, 2021

(CC BY 4.0) | ISSN 2525-3409 | DOI: http://dx.doi.org/10.33448/rsd-v10i9.17194

Parreiras, S. O., Favoreto, M. W., Lenz, R. E., Serra, M. E., Borges, C. P. F., Loguercio, A. D., \& Reis, A. (2020). Effect of prior application of desensitizing agent on the teeth submitted to in-office bleaching. Brazilian Dental Journal, 31(3), 236-243. 10.1590/0103-6440202003365

Peixoto, A. C., Vaez, S. C., Soares, K. D., Ferreira, L. F., Loguercio, A. D., \& Faria-E-Silva, A. L. (2019). Preemptive use of piroxicam on tooth sensitivity caused by in-office bleaching: a randomized clinical trial. Brazilian Dental Journal, 30(5), 498-504. 10.1590/0103-6440201902762

Pereira, R., Gillam, D. G., Bapatla, S., \& Satyamurthy, P. (2018). Awareness of dentine hypersensitivity among general dental practitioners in Mumbai, India. Journal of Odontology, 2(1), 1000103. Retrieved from https://www.longdom.org/open-access/awareness-of-dentine-hypersensitivity-among-general-dentalpractitioners-in-mumbai-india.pdf

Raposo, F., de Carvalho Rodrigues, A. C., Lia, É. N., \& Leal, S. C. (2019). Prevalence of hypersensitivity in teeth affected by molar-incisor hypomineralization (MIH). Caries Research, 53(4), 424-430. 10.1159/000495848

Schuurs, A. H., Wesselink, P. R., Eijkman, M. A., \& Duivenvoorden, H. J. (1995). Dentists' views on cervical hypersensitivity and their knowledge of its treatment. Endodontics and Dental Traumatology, 11(5), 240-244. 10.1111/j.1600-9657.1995.tb00496.x

Splieth, C. H., \& Tachou, A. (2013). Epidemiology of dentin hypersensitivity. Clinical Oral Investigations, 17 Suppl 1(Suppl 1), S3-S8. 10.1007/s00784-012$0889-8$

Zeola, L. F., Teixeira, D. N. R., Galvão, A. D. M., Souza, P. G., \& Soares, P. V. (2020). Brazilian dentists' perception of dentin hypersensitivity management. Brazilian Oral Research, 33, e115. 10.1590/1807-3107bor-2019.vol33.0115 